\title{
Technology Transfer as the Third Role of Universities \& National Platform in the Czech Republic
}

\section{Růžena ŠTEMBERKOVÁ ${ }^{,}$, Dagmar ŠKODOVÁ-PARMOVÁ ${ }^{2}$, Petra MAREŠOVÁ ${ }^{1 *}$ and Petr OČKO ${ }^{3}$}

1 University of Hradec Králové, Hradec Králové, Czech Republic; ruzena.stemberkova@uhk.cz; petra.maresova@uhk.cz

2 University of South Bohemia, České Budějovice, Czech Republic; parmova@ef.jcu.cz

3 Silesian University in Opava, Opava, Czech Republic; petr.ockofpf.slu.cz

* Corresponding author: petra.maresova@uhk.cz

\begin{abstract}
In recent years, the third role of universities has enjoyed a great support and development not only in the world, but also in the Czech Republic. The individual transfer centers and offices establish themselves within their home research institutions and expand the growth of their activities. At the same time, they are an integral part and the main service workplace within a comprehensive system of support for the protection of intellectual property and commercialization. These centers, along with other professionals in their fields in many countries, have created national knowledge transfer platforms that bring together all those who are interested in and support this field. The aim of this article is to compare the development of technology and knowledge transfer in the Czech Republic with chosen situation abroad so that possible further promising directions for this area can be determined.
\end{abstract}

Keywords: knowledge transfer; technology transfer; national association; roles of universities

JEL Classification: $\mathrm{O} 30$

\section{Introduction}

Technology transfer as the third role of universities has enjoyed a great support and development not only in the world, but also in the Czech Republic. The individual transfer centers and offices establish themselves within their home research institutions and expand the growth of their activities.

In the international context, there are different point of views on what exactly the term technology transfer refers to. Technology transfer, there can be found terms such as knowledge transfer or knowledge exploitation (Jonsson, 2008; Riege, 2007; King, in Schwartz (ed.), 2006), which try to put more stress on the role of social sciences and the humanities. Other authors (such as Benneworth and Jongbloed (2009)) also use the term valorization, which can be understood in terms of utilization, as it refers to the added value beyond purely scientific outputs, and broadly includes any social benefit, not exclusively economic. The OECD's (2007) approach to the third role of universities, which is also very close to the approach applied in the strategic documents of the European Union, emphasizes the connection between the academic and applied spheres and connects the process of knowledge transfer traditionally with its economic benefits. In this sense, university institutions serve as key elements of 
regional development. The role of universities is to explore critically at the causes and consequences of the emergence of global social problems, and the knowledge generated at universities should address and alleviate social and economic disparities between developed and developing countries UNESCO (GUNI 2008). The European Commission considers the involvement of public research organizations in the protection of intellectual property and knowledge transfer to be essential for generating socioeconomic benefits and for attracting students, researchers, and further funding. Licensing and the creation of spin-off companies are regarded as the main pillars of knowledge transfer. Knowledge transfer should therefore, in accordance with the principles of responsible research and innovations, strive to fulfil its primary aim of maximizing the social impact of knowledge and technology transfer, while taking into account criteria of financial efficiency and contributing to the competitiveness of domestic industry.

\section{Methodology}

The aim of this article is to compare the development of technology and knowledge transfer in the Czech Republic with chosen situation abroad, try to identify factors for comparison so that possible further promising directions for this area can be determined. In terms of the choice of countries, we chose Poland for comparison, which is our neighboring country and belongs together with the Czech Republic to the V4. It is a state that historically belonged to the Eastern bloc. As a second country for comparison, we chose Italy, a representative from the former Western Europe historically belonging to the G7 bloc. The Western bloc historically supports and communicates these activities for much longer period of time. Italy, a country that has been supporting the field of knowledge transfer for a longer time than the Czech Republic and is a representative example of the Western Europe. The other selected country is Poland, which has been working with technology and knowledge transfer for a shorter period of time than the Czech Republic. However, in the past, both these countries created and developed a national platform that brings together regional and local transfer centers and offices, as well as all professionals in the field who expressed an interest in the platform membership.

For this purpose, the desk research method was used, which involves the collection and analysis of secondary data, especially in electronic form. Sources used include databases, already existing available research, reports of selected organizations, and other sources.

This research answer question: What are the national technology transfer platforms? Are their activities comparable?

\section{National Technology Transfer Platform in the Czech Republic}

The need for the establishment of a national platform in the Czech Republic arose primarily from European models of other countries and also from national discussions within the emerging and growing technology transfer offices at Czech public universities and academic institutions. These two factors led to the creation of a national technology transfer platform. 
Transfera.cz was established on November 11, 2014 by a transformation of the Association of Knowledge Transfer Organizations and Professionals (AKTOP), which was a precursor of the present platform. From 2008, AKTOP operated as a voluntary civic association of individuals and institutions engaged in discovering, protecting, and commercializing new research findings, knowledge transfer, and the use of new knowledge for innovative entrepreneurship. The national platform Transfera.cz defends the interests of the transfer community in the Czech Republic with the aim of strengthening and developing activities in the field of technology and knowledge transfer. Through the activities of this association at the national level and all our members, relations between the academic and commercial spheres are strengthened in general; support for the development of innovations with the aim of strengthening the competitiveness of the Czech Republic at the international level; be an erudite partner of relevant public administration bodies; provide information, expert opinion and technology and knowledge transfer analysis; establish international cooperation with similar foreign associations and to facilitate the dissemination of research and development results.

In this context, it is necessary to point out that the national Transfera.cz platform has already become a consulting authority for several government departments, the Industrial Property Office, and the Technology Agency of the Czech Republic, who address the association to consult issues related to this topic. Similarly, based on the needs of its own members, a number of current working groups have emerged within this platform to address important issues and share their own practice, such as the PoC group, marketing and project group, legislative group, and last but not least a database group. Each of these groups meets approximately once a month and the subsequent results are presented to the Transfera.cz board.

\subsection{Development of Members of the National Transfera.cz Platform}

It should be mentioned at the outset that the representatives of the Czech national platform do not strive for the growth of their membership but seek to attract professionals who a connection to the association's main objectives, can generate significant benefits for the transfer community in the Czech Republic, and help in connecting the worlds of academia and commerce.

Table 1. Transfer community in the Czech Republic

\begin{tabular}{|c|c|c|}
\hline Transfera.cz Membership & November 2014 & November 2020 \\
\hline Universities & 8 & 18 \\
\hline Science academies & 1 & 11 \\
\hline Patent attorneys & 0 & 2 \\
\hline Other & 2 & 11 \\
\hline
\end{tabular}

Note: As of November 8, 2020, Transfera.cz had 42 members, out of which 18 members were representatives of public universities. A total of 26 public universities are registered in the Czech Republic, so it is clear that the vast majority are also members of the national Transfera.cz platform. Following the universities are institutes of the Czech Academy of Sciences, out of which 11 were members as of the given date. 


\section{Comparison with other EU Countries -Italy and Poland}

Within the countries of the European Union, we have selected for a more comprehensive comparison two national transfer associations described below, one operating in Italy under the name Netvala and the other in Poland under the name PACTT.

\subsection{Italy}

The Italian association is the older platform and was founded in 2002. This organization at first existed as an information network which connected its members and became an association only in 2007. "Netval's mission is to be the organization where Technology Transfer Offices (TTOs) of Italian universities and public research organizations can meet, share experiences and learn together how to better transfer their research results to industry" (NETVAL, 2021).

Netval strives to become an important interface for ministries and local administrations, industrial associations and industries, venture capitalists, and financial bodies to strengthen the position of the third role of universities and support the connection of academia with the commercial sphere. At the same time, however, it seeks to promote the role of public research in innovation processes. The Netval association started with a bottom-up approach, primarily in order to obtain support from research and development result holders and subsequently their management, which gradually led to support for technology transfer at scientific research institutions. Netval is and intends to remain an independent association, but it has very good relations with MIUR (Ministry of Education, University, and Research), MISE (Ministry of Economic Development), CRUI (Conference of Italian University Rectors), and many other organizations in the Italian ecosystem of innovation and technology transfers.

Netval's national and international concrete objectives are: to help its associates in improving their activities in the field of the protection and exploitation of research results from public research through education, dissemination, patenting, licensing, public-private cooperation and start up promotion; to improve the links between universities and companies in order to further enhance the production and transfer of research results; to foster the generation of new companies from public research. It is therefore a comprehensive coverage of all activities that fall into the field of commercialization.

In terms of membership, the Netval association currently includes 57 out of a total of 100 Italian universities. Furthermore, members of the Netval association include four academic scientific institutions, two foundations, one agency, and seven individual professionals.

Comparing the total number of universities in Italy and the number of university members who are part of the Netval platform, it is clear that more than half of them $(57 \%)$ are members. In terms of the involvement and interconnection of researchers, Netval brings together $69 \%$ of professors from all over Italy, which testifies to the prestigious view of this association within Italy and also confirms that the original Netval network was developed with the bottom-up approach. 


\subsection{Poland}

The other country we have chosen is Poland, where the area of knowledge transfer has a shorter history. Here, too, representatives of technology transfer offices created and built a national platform to promote the interests of knowledge transfer.

The Polish Association of Centers for Technology Transfer (PACTT.pl) is a voluntary association of representative units of Polish universities. It is therefore similar to both the Czech and Italian industry platforms. The main focus of this association is relevant to the whole area of knowledge transfer, which includes the protection, management, and commercialization of university intellectual property.

The idea of creating PACTT is in Poland not old, as it was born in 2015. The purpose of establishing the joint venture was the cooperation of similar units in the field of broadly understood commercialization of scientific research results, exchange of good practices, and experience, and, among others, the implementation of EU projects. The Polish association is very active in the mutual exchange of information and mutual cooperation with other national associations. It seeks to establish itself on both the European and international scene and to share examples of good and bad practice for further coordinated development. The core of the joint venture is the active cooperation of units and the representation of PACTT members in order to establish contacts with entrepreneurs, the creation of the university image as that of an institution open to the non-academic environment and adapted to the dynamically changing market situation and the expectations of the business environment.

The very foundation of this organization is interesting because in December 2015, representatives of six technology transfer offices (AGH University of Science and Technology, Gdańsk University of Technology, Silesian University of Technology, Wrocław University of Science and Technology, Jagiellonian University, West Pomeranian University of Technology in Szczecin) decided to enter into a partnership by establishing the Polish Association of Centers for Technology Transfer (PACTT.pl).

Nowadays, the association comprises a network of technology transfer centers of Polish universities, and approximately 65,000 scientists and 14,000 patents, and is open to new members (only TTOs). This national association is a member of Association of European Science and Technology Transfer Professionals (ASTP) and National Associations Advisory Committee (NAAC).

Currently, the joint venture consists of 73 units, mostly public but also private, and the number of participants increases from year to year (https://pactt.pl/en/about-pactt). The membership base is represented in the following breakdown: public universities are represented by 57 members, private universities by four members, institutes of the Polish Academy of Sciences by four members, public institutions by four members, and higher professional schools also by four members. In Poland there are in total 132 public and 306 private institutions of higher education (universities and colleges).

PACTT organizes annual nationwide conferences for its members, attended by 200-300 people. Conference programs include meetings with stakeholders (ministry, other governmental institutions, associations of university rectors, investors, etc.); expert 
workshops (IP valuation, license agreements, tax law, patent law); benchmarking, and exchange of best practices.

PACTT decided to create six working groups, one each for the creation of joint technology offers of PACTT members; for the development of model technology transfer agreements (Polish "Lambert Toolkit"); for the standardization of processes and tasks of technology transfer offices; for the creation of the key competences list for technology transfer professionals; for interacting and lobbying with key stakeholders; and for international cooperation (ProgressTT and ASTP-Proton NAAC member). PACCT does not have other members than TTOs/CTTs, no attorneys etc. Current split of members between universities, academy of sciences and higher vocational schools. There is a separate organization in Poland, grouping Special Purpose Vehicles (in Polish: spółki celowe). These are LLC s owned $100 \%$ by universities, which take shares in university start-ups.This organization is called "Porozumienie Spółek Celowych" (PSC) and it groups 24 SPVs from Poland. Both organizations, PACTT and PSC work together very closely.

Table 2 Activity of platforms for the support of technology transfer

\begin{tabular}{|c|c|c|c|}
\hline $\begin{array}{c}\text { Compariosn of technology } \\
\text { transfer platforms }\end{array}$ & Czech Republic & Poland & Italy \\
\hline Established & 2014 & 2015 & 2007 \\
\hline Number of members & 42 & 73 & 71 \\
\hline $\begin{array}{l}\text { Members "mixed" } \\
\text { (universities, academia, } \\
\text { another units) }\end{array}$ & $x$ & & $x$ \\
\hline $\begin{array}{c}\text { Number of universities 's } \\
\text { members }\end{array}$ & 18 & 57 & 57 \\
\hline $\begin{array}{c}\text { Organisation of national } \\
\text { conference }\end{array}$ & $x$ & $X$ & $x$ \\
\hline $\begin{array}{l}\text { Organisation of worskhops } \\
\text { for profesionals }\end{array}$ & $x$ & $X$ & $x$ \\
\hline Working groups & $x$ & & $x$ \\
\hline $\begin{array}{c}\text { Patents where participate } \\
\text { academic institutions (source: } \\
\text { database Patent Inspiration) }\end{array}$ & $\begin{array}{l}\text { Year } 2018-86 \\
\text { Year } 2019-112 \\
\text { Year } 2020-108\end{array}$ & $\begin{array}{r}\text { Year } 2018-1,732 \\
\text { Year } 2019-1,845 \\
\text { Year } 2020-1,711\end{array}$ & $\begin{array}{l}\text { Year } 2018-275 \\
\text { Year } 2019-277 \\
\text { Year } 2020-294\end{array}$ \\
\hline $\begin{array}{l}\text { Patents where participate } \\
\text { academic institutions per one } \\
\text { hundred thousand inhabitants } \\
\text { (source: database Patent } \\
\text { Inspiration) }\end{array}$ & $\begin{array}{l}\text { Year } 2018-8.0 \\
\text { Year } 2019-10.5 \\
\text { Year } 2020-10.1\end{array}$ & $\begin{array}{l}\text { Year } 2018-45.6 \\
\text { Year } 2019-48.6 \\
\text { Year } 2020-45.1\end{array}$ & $\begin{array}{l}\text { Year } 2018-4.6 \\
\text { Year } 2019-4.6 \\
\text { Year } 2020-4.9\end{array}$ \\
\hline
\end{tabular}

\subsection{International Mutual Comparison}

Considering the above, it is clear that technology transfer professionals are coming together and networking, at both national and international levels, to share information, exchange good practice, and create support for an innovative ecosystem. The area of developing the third pillar of universities is relatively new in some countries, such as in Israel or the United States. Based on the above examples, it is clear that the sharing of good practice 
and the creation of working groups to support the individual activities involved in knowledge transfer are important in that they create a lobby mechanism and not only help increase the establishment of knowledge transfer between the sphere of research and development and that of business but also promote networking especially between SMEs and innovation holders and, last but not least, help increase the competitiveness of individual regions and national units. Looking at the comparison of national technology transfer support platforms, it seems that the answer to the questions of whether their activities are similar and close the answer is that mostly yes. Poland has the largest number of members, as is the most populous of the countries under comparison, but almost identical to Italy. Both in the Czech Republic and Italy, various types of entities participate in the platforms and subworking groups are formed. If we also look at the patent activity of public institutions, which have the potential to be subsequently the subject of attention of these platforms, then Poland is clearly the leader in this regard. Italy has the least per 100,000 inhabitants.

\section{Discussion and Conclusion}

Public universities are traditionally focused on teaching and research. Universities have a positive influence on employment, development of industry and services through innovations, cultural potential (cultural activities, popularizing lectures), social care capacities. The ways in which universities handle their innovations and knowledge differ both in their form and their scale, where they may cooperate locally, regionally, or and globally. The cooperation of universities with employers primarily involves representatives of industry, services, and state administration, but the cooperation also includes profiling study programs, setting up science and technology parks, incubators, and start-ups, and engaging business professionals in teaching.

In order to find recommendations for the further direction of these platforms, it will be necessary to focus on other scales of facts. The findings so far point to an ambiguous relationship between platform activity and patent activity; attention in further research will focus on commercialized solutions that may be more closely linked to the activities of these platforms.

The third role of universities in the strategic documents of the Ministry of Education, Youth and Sports is included in the long-term plan of the ministry, which states: "In addition to educational and creative activities, an equally important role of universities is their direct social impact and what is known as their 'third role' in general. Universities contribute to the dissemination of knowledge and values in society in many different ways." This is explained further in strategic goal no. 4, "Relevance", which stipulates: "Universities will reflect in their activities the current social developments, the latest scientific knowledge, and the needs of their partners. Universities will be in a close and mutually open contact with partners at local, national, and international levels, with graduates, employers, scientific and academic institutions, as well as with the non-profit sector and public administration." Within the framework of various models applied in an international context, the creation of national platforms is approached, which defend their professional interests in various ways. 
In some countries, such as Italy, the members of the national platform are various representatives not only from the university environment, but also from the commercial environment. In some countries, this matter is approached differently - the core and basic organizations are made up exclusively and exclusively of representatives from the university environment. The other interested parties then form another separate association, however, the two groups / platforms communicate and cooperate very well. This system largely guarantees the provision of continuous focus and targeting of the association on the set activities. In the case where the members of the platform are different interest groups from different fields, the original intentions and goals may change.

The Czech Republic joined countries that have their own professional national technology and knowledge transfer platform, which is a distinctive and constantly evolving body since its inception. Its members are professionals and representatives of institutions or companies that seek to promote the development of the third pillar, connect the academic and corporate worlds, and share good and bad practice. This professional platform always focuses on addressing current problems and trends and has become a recognized authority in the Czech Republic, helping to solve issues, provide consultations, and explain questions related to technology transfer. The same direction of development and support of technology transfer can be observed also in other European countries, such as Italy, where the history of technology transfer is longer. The current situation is no different in Poland, where, on the contrary, the history of technology transfer is shorter than in the Czech Republic.

Acknowledgement: This work was supported by the Technology Agency the Czech Republic TL02000066“Effective knowledge transfer management “. In addition, I would like to thank prof. Ondrej Krejcar for providing data on patent activity of countries.

\section{References}

Benneworth, P., \& Jongbloed, B. W. (2010). Who matters to universities? A stakeholder perspective on humanities, arts and social sciences valorisation. Higher Education, 59(5), 567-588. https://doi.org/10.1007/s10734-009-9265-2

Bílá kniha terciárního vzdělávání, MŠMT ČR. (n.d.). Retrieved February 2, 2021, from https://www.msmt.cz/reforma-terciarniho-vzdelavani/bila-kniha

Commercialising Intellectual Property: Joint Ventures I European IP Helpdesk. (n.d.). Retrieved February 2, 2021, from https://www.iprhelpdesk.eu/Fact-Sheet-Commercialising-IP-Joint-Ventures

European Commission. Directorate-General for Research. (2008). Commission recommendation on the management of intellectual property in knowledge transfer activities and Code of Practice for universities and other public research organisations. Publications Office. https://data.europa.eu/doi/10.2777/13162

European IPR Helpdesk (CZ) I European IP Helpdesk. (n.d.). Retrieved February 2, 2021, from https://www.iprhelpdesk.eu/services/cz

Higher Education in the World 3. (2015, March 24). Guni Network. http://www.guninetwork.org/report/highereducation-world-3

Integrated local development at the OECD Trento Centre - OECD. (n.d.). Retrieved February 2, 2021, from http://www.oecd.org/cfe/leed/trento-centre-integrated-local-development.htm

IPN EF-TRANS / Efektivní transfer znalostí a poznatků z výzkumu a vývoje do praxe a jejich následné využití, MŠMT ČR. (n.d.). Retrieved February 2, 2021, from https://www.msmt.cz/vzdelavani/vysoke-skolstvi/ipnef-trans-efektivni-transfer-znalosti-a-poznatku-z

Jonsson, A. (2008). A transnational perspective on knowledge sharing: lessons learned from IKEA's entry into Russia, China and Japan. The International Review of Retail, Distribution and Consumer Research, 18(1), 17-44. https://doi.org/10.1080/09593960701778044 
Krčmařová, J. (2010). Dvě cesty ke třetí roli vysokých škol. Srovnaní a konceptualizace OECD a UNESCO. Aula, 18(4), 17-29.

Ministry of Education. (2015). Long-term plan Ministry of Education. 2016-2020. Retrieved February 2, 2021, from https://www.msmt.cz/vzdelavani/vysoke-skolstvi/dlouhodoby-zamer

National platform of transfer community. Transfera.cz. Retrieved February 2, 2021, from http://www.transfera.cz/

NETVAL I Netval. (n.d.). Retrieved February 2, 2021, from https://netval.it/netval-italian-network-oftechnology-transfer-offices-of-universities-and-public-research-organizations/

OECD. (2007). Higher Education and Regions: Globally Competitive, Locally Engaged. OECD Publishing, Paris. https://doi.org/10.1787/9789264034150-en

PACTT - Porozumienie Akademickich Centrów Transferu Technologii. (n.d.). Retrieved February 2, 2021, from https://pactt.pl/en/about-pactt

Paulin, D., \& Suneson, K. (2012). Knowledge Transfer, Knowledge Sharing and Knowledge Barriers - Three Blurry Terms in KM. Electronic Journal of Knowledge Management, 10, 82-92.

Riege, A. (2007). Actions to overcome knowledge transfer barriers in MNCs. Journal of Knowledge Management, 11(1), 48-67. https://doi.org/10.1108/13673270710728231

Schwartz, D. (Ed.). (2006). Encyclopedia of Knowledge Management. IGI Global. https://doi.org/10.4018/978-1-59140573-3

Tech transfer: Europe vs the US - a personal view. (n.d.). Science I Business. Retrieved February 2, 2021, from https://sciencebusiness.net/news/69010/Tech-transfer\%3A-Europe-vs-the-US-\%E2\%80\%93-a-personal-view 